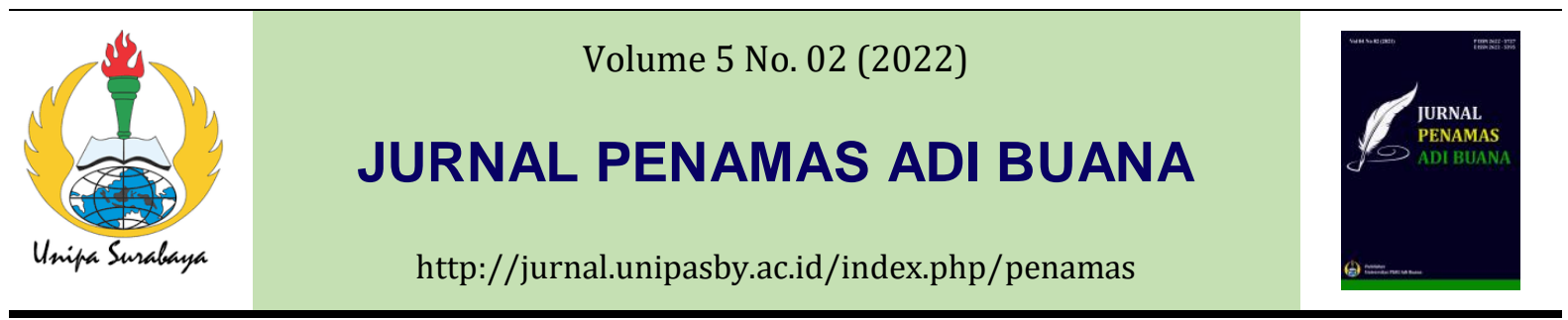

\title{
PELATIHAN DAN PENDAMPINGAN PEMBUATAN MEDIA PROMOSI BERBASIS TEKNOLOGI INFORMASI TERHADAP PRODUK-PRODUK UNGGULAN DAERAH DAN OBJEK WISATA DI KABUPATEN LAMONGAN
}

\author{
Cicik Alfiniyah $^{1}$, Nashrul Millah ${ }^{1 *}$, Asri Bekti Pratiwi ${ }^{1}$ \\ ${ }^{1}$ Program Studi Matematika, Universitas Airlangga, Surabaya, Indonesia \\ *Email: nashrul.millah@fst.unair.ac.id
}

\begin{abstract}
Informasi Artikel Abstrak
Kata kunci:

Media promosi, produk unggulan, teknologi informasi, wisata alam daerah

Diterima: 30-09-2021

Disetujui: 05-01-2022

Dipubikasikan: 31-012022

Salah satu sebab rendahnya perkembangan potensi ekonomi daerah adalah kurang tersebarnya informasi terkait produk-produk unggulan dan wisata alam daerah pada masyarakat luas. Hal ini mendasari dilakukannya program pengabdian kepada masyarakat di desa Kranji yang dilaksanakan oleh tim dari Program Studi Matematika Fakultas Sains dan Teknologi Universitas Airlangga. Kegiatan yang dilakukan meliputi pelatihan dan pendampingan pembuatan website sebagai media promosi produk-produk unggulan dan wisata daerah berbasis teknologi informasi. Melalui kegiatan ini, diharapkan dapat membantu penyebaran informasi terkait potensi daerah agar dikenal oleh masyarakat luas sehingga meningkatkan pendapatan masyarakat sekitar desa Kranji. Kegiatan ini dilakukan dalam empat tahapan, yaitu: koordinasi, pelatihan, pendampingan, dan evaluasi. Keberhasilan pelatihan dievaluasi dari nilai pretest dan posttest peserta yang menunjukkan adanya peningkatan sebesar $25 \%$. Selain itu, didapatkan output berupa website yang telah dibuat oleh peserta berisikan potensipotensi desa Kranji. Hasil evaluasi terhadap materi, narasumber, dan fasilitas pelatihan juga menunjukkan respon positif dari peserta dengan nilai 4,3 dari skala 5 .
\end{abstract}

Keywords :

Promotional media, superior products, information technology, regional nature tourism

\section{Abstract}

One of the reasons for the low development of regional economic potential is the lack of information related to superior products and regional natural tourism in the wider community. This is the reason for community service program in Kranji village held by Department of Mathematics, Faculty of Science and Technology Universitas Airlangga. This program includes training and mentoring to create websites to promote superior products and regional tourism based on information technology. Through this activity, it is expected to help the dissemination of regional resources information to be known by the wider community so as to increase the income of the community around Kranji village. This activity is carried out in four stages, namely coordination, training, mentoring, and evaluation. The training was evaluated from the pretest and posttest grades which showed a $25 \%$ 
increase. In addition, the output is obtained in the form of a website that has been created by participants containing the potentials of Kranji village. The evaluation of materials, speaker, and training facilities also showed a positive response from participants with a score of 4.3 from a scale of 5 .

\section{PENDAHULUAN}

Pembangunan ekonomi yang dijalankan daerah saat ini masih belum mampu meningkatkan kesejahteraan masyarakat secara signifikan. Hal tersebut disebabkan kurang berkembangnya potensi ekonomi daerah yang berakibat pada rendahnya daya saing ekonomi daerah tersebut (Rosyid dkk., 2020). Kurang tersebarnya informasi terkait produk-produk unggulan daerah ataupun potensi wisata alam daerah pada masyarakat luas menjadi salah satu sebab rendahnya perkembangan potensi ekonomi daerah. Banyak produk-produk unggulan daerah yang sebenarnya memiliki potensi tinggi untuk meningkatkan kesejahteraan masyarakat lokal bahkan bisa bersaing di pasar internasional . Jika hal ini terjadi, akan sangat membantu peningkatan ekonomi daerah (Nadhiroh, 2018). Sebab hasil penelitian menunjukkan bahwa ekspor merupakan salah satu faktor yang mempengaruhi tingkat pertumbuhan ekonomi di Indonesia (Syahputra, 2017). Disamping produk unggulan daerah, banyak potensi wisata di Indonesia yang belum dikenal oleh masyarakat sekitar tempat wisata, khususnya di wilayah regionalnya, padahal obyek wisata yang ada telah beroperasi cukup lama. Salah satu contohnya adalah objek wisata potensial yang ada di Lamongan seperti yang tersaji pada Gambar 1 .

Melalui identifikasi produk daerah apa saja yang dapat diunggulkan dan wilayah alam mana saja yang dapat dikembangkan, maka masyarakat mampu mengenali potensi apa saja yang dapat dijadikan sebagai kekuatan ekonomi daerah tersebut. Penyebaran informasi pada era digitalisasi pada masyarakat luas diharapkan mampu menumbuhkan produk-produk unggulan ataupun sektor pariwisata daerah yang berakibat banyak terserapnya tenaga kerja lokal dan dapat meningkatkan pendapatan ataupun kesejahteraan masyarakat sekitar (Romhadhoni dkk., 2018; Wardana dkk., 2014). 


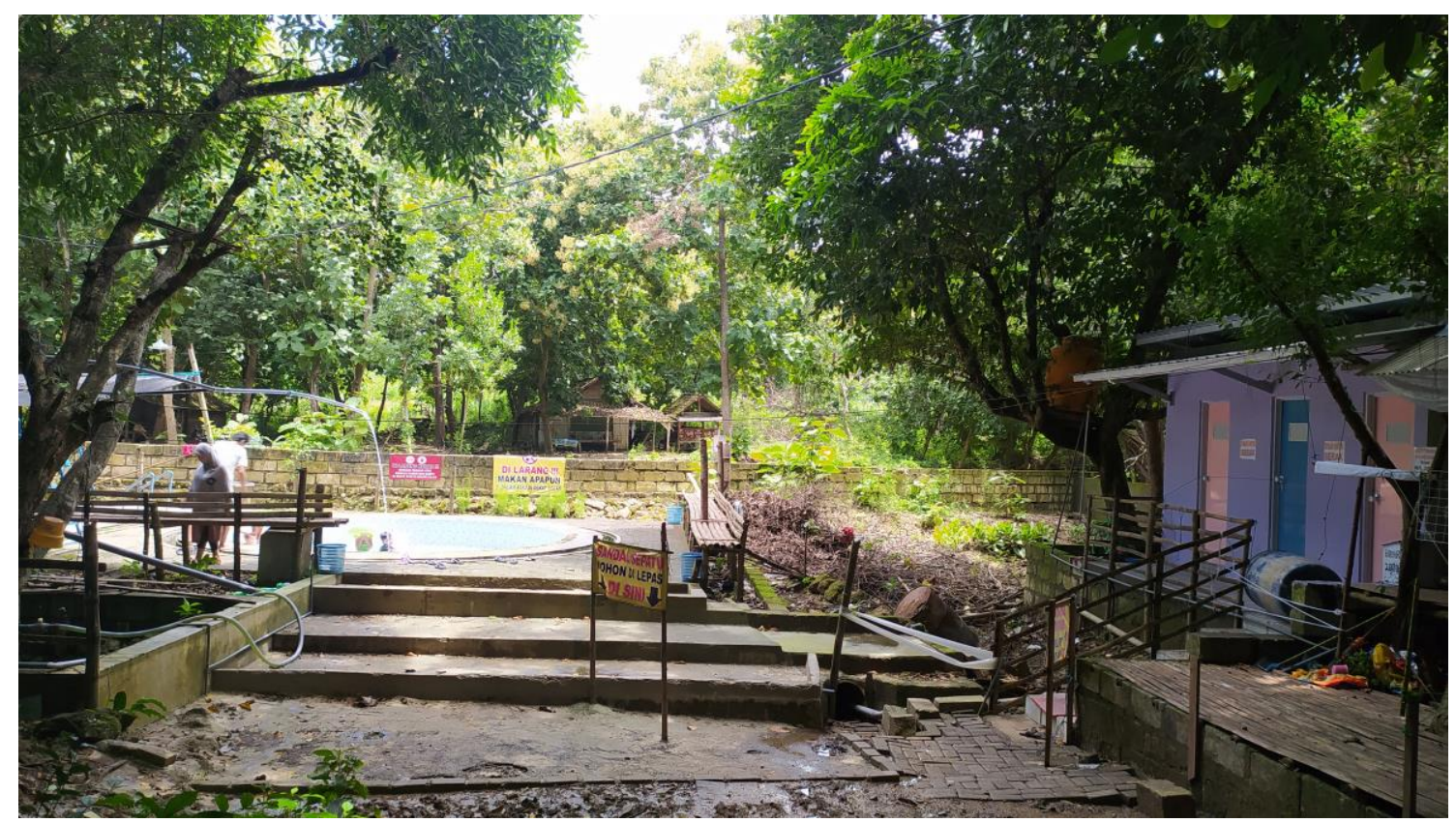

Gambar 1. Kondisi Wisata lokal desa Kranji yang belum banyak dikenal masyarakat.

Penggunaan teknologi informasi merupakan cara yang sangat efektif untuk menunjang penyebaran informasi, utamanya yang berkaitan dengan pariwisata. Saat ini, banyak masyarakat yang memanfaatkan media sosial untuk merencanakan dan memandu kegiatan wisata mereka. Beragam informasi dapat diakses, bahkan yang berkaitan dengan wisata-wisata di daerah terpencil sekalipun (E.Prasetyo, 2019). Mulai dari mencari informasi wisata yang menarik, mencari tahu cara untuk mengakses wisata tersebut, hingga mendokumentasikan kegiatan wisata mereka (Rizkinaswara, 2019). Hal ini menunjukkan bagaimana pentingnya penggunaan teknologi informasi untuk mengembangkan objek wisata daerah.

Usaha untuk mengeksploitasi bagi kepentingan pariwisata dengan memperhatikan kelestariannya akan menjamin kelangsungan lingkungan hidup secara keseluruhan sekaligus menjamin kelangsungan kepariwisataan pada daerah itu sendiri. Oleh karena itu, peran pemerintah ataupun akademisi sangat diperlukan dalam mendorong keberhasilan usaha daerah baik berupa produk atupun jasa. Salah satunya dengan memperluas akses komunikasi melalui pelatihan ataupun fasilitasi penggunaan teknologi informasi yang dapat digunakan sebagai media komunikasi secara global (Ritchi dkk., 2018). Melalui program ini juga diharapkan dapat mewujudkan Smart Tourism yang tidak hanya memiliki sumber daya alam yang potensial tapi juga difasilitasi oleh penggunaan media komunikasi modern, seperti website dan media sosial (Putra dkk., 2020) serta aplikasi penunjang pekerjaan seperti todoist (Komalasari, 2020).

Departemen Matematika Fakultas Sains dan Teknologi, sebagai salah satu departemen di Universitas Airlangga yang mumpuni dalam masalah teknologi informasi, turut berkontribusi meningkatkan kemampuan masyarakat dalam penguasaan teknologi informasi sebagai media 
pengembangan usaha daerah. Yaitu dengan mengadakan pelatihan pembuatan dan pengelolaan website dan media sosial sebagai wadah publikasi produk-produk unggulan dan potensi wisata daerah. Pelatihan tersebut dilaksanakan oleh tim pengabdian masyarakat departemen Matematika Fakultas Sains dan Teknologi Universitas Airlangga dan merupakan bagian dari program pengabdian kepada masyarakat berkelanjutan yang akan diterapkan pada masyarakat di Kota Lamongan.

\section{METODE}

Berdasarkan analisis situasi yang telah diuraikan pada Bab 1, tim pelaksana pengabdian kepada masyarakat, Departemen Matematika Fakultas Sains dan Teknologi (FST) Universitas Airlangga telah mengadakan kegiatan pelatihan dan pendampingan pengembangan sistem informasi dan media promosi produk unggulan daerah dan objek wisata di Kabupaten Lamongan dengan sasaran peserta berjumlah 20 orang. Kegiatan ini diharapkan mampu memberikan kontribusi dalam peningkatan kualitas media promosi produk unggulan daerah dan objek wisata yang berdampak pada peningkatan pemasaran produk unggulan daerah dan jumlah pengunjung objek wisata, sehingga secara tidak langsung meningkatkan perekonomian masyarakat sekitar. Kegiatan pengabdian kepada masyarakat ini dilaksanakan secara bermitra atau kolaborasi antara tim pelaksana yang terdiri dari dosen Departemen Matematika FST Universitas Airlangga dengan pemerintah desa Kranji. Kegiatan pengabdian kepada masyarakat ini terdiri atas empat tahap sebagaimana ditunjukkan pada Gambar 2.

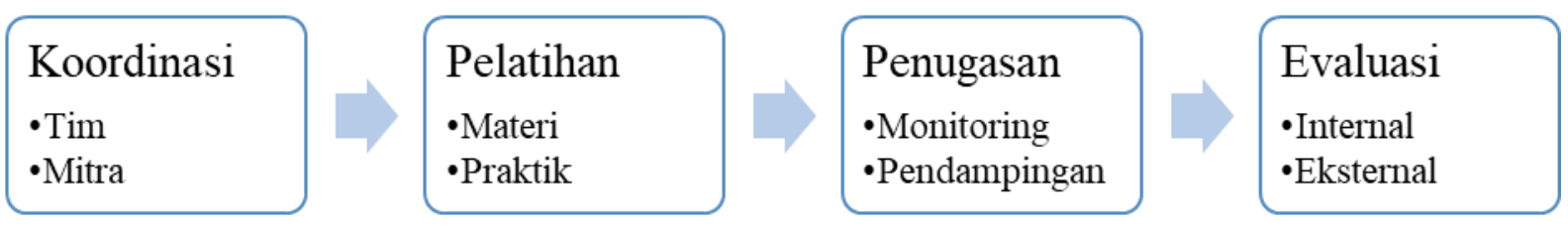

Gambar 2. Tahapan pelaksanakan program pengabdian kepada masyarakat

1. Koordinasi pelaksanaan kegiatan dilakukan baik dengan tim pelaksana pengabdian kepada masyarakat maupun dengan mitra, dalam hal ini pemerintah desa Kranji. Koordinasi diperlukan untuk mempersiapkan segala sesuatu terkait pelaksanaan kegiatan sekaligus meminimalisir kendala pada saat pelaksanaan.

2. Pelaksanaan pelatihan pengembangan sistem informasi dan media promosi dilakukan secara luring selama satu hari bertempat di Balai Desa Kranji. Pelatihan terdiri atas sesi penyampaian materi dan praktik langsung dari peserta didampingi oleh tutor.

3. Penugasan pembuatan sistem informasi berupa website yang berisikan informasi terkait potensi-potensi daerah kranji, meliputi produk-produk unggulan dan destinasi wisata. Penugasan dilakukan dalam rentang waktu satu bulan sejak dilaksanakannya pelatihan dengan didampingi oleh tim pelaksana pengabdian kepada masyarakat. Monitoring dilakukan untuk memastikan peserta melaksanakan tugas yang telah diberikan. 
4. Evaluasi dilakukan baik dari internal maupun eksternal. Evaluasi internal didapatkan dari panitia pelaksana sedangkan evaluasi eksternal didapatkan dari umpan balik peserta terhadap pelaksanaan kegiatan pelatihan. Untuk mengukur keberhasilan program yang ditandai dengan peingkatan pemahaman peserta terhadap materi yang disampaikan, maka dilakukan pretest dan posttest.

\section{HASIL DAN PEMBAHASAN}

Kegiatan pelatihan dan pendampingan pengembangan sistem informasi dan media promosi produk unggulan daerah dan objek wisata dilaksanakan selama satu hari pada hari Selasa, 7 September 2021. Kegiatan ini dihadiri oleh 20 peserta yang berasal dari pemuda pemudi desa Kranji Kecamatan Paciran, Lamongan. Pemilihan peserta dilakukan oleh sekretaris desa berdasarkan keterwakilan bidang-bidang yang ada di desa Kranji, seperti : bidang pariwisata, ekonomi, pendidikan, dan sebagainya. Selain itu, pemilihan juga didasarkan pada kemampuan dasar peserta di bidang IT. Hal ini dilakukan agar pelaksanaan pelatihan berjalan secara optimal serta memberikan hasil yang maksimal untuk dapat dimanfaatkan di tiap-tiap bidang.

Berdasarkan hasil analisis terhadap nilai pretest dan posttest, didapat adanya peningkatan pengetahuan peserta terkait topik yang disampaikan. Hasil posttest menunjukkan rata-rata nilai peserta 6 poin dari skala 10, naik 25\% dari rata-rata nilai pretest yang hanya 4,5 poin. Meski kenaikan nilai ini tidak cukup besar, namun kegiatan pengabdian kepada masyarakat ini bisa dikatakan berhasil jika dilihat dari kualitas output yang dihasilkan, yaitu berupa website yang dapat diakses pada tautan https://wisatalamongan.com. Dari kegiatan pelatihan dan pendampingan yang dilakukan, peserta berhasil membuat sebuah website yang merupakan hasil kerjasama seluruh peserta. Dimana pada saat pelatihan, peserta dibagi menjadi lima kelompok untuk mengelola halaman websitesesuai bagian masing-masing, yaitu: beranda, destinasi, prokes, artikel, dan kontak kami. Gambar 3 menunjukkan tangkapan layar halaman website yang telah dibuat oleh peserta pada kegiatan pengabdian kepada masyarakat ini. 


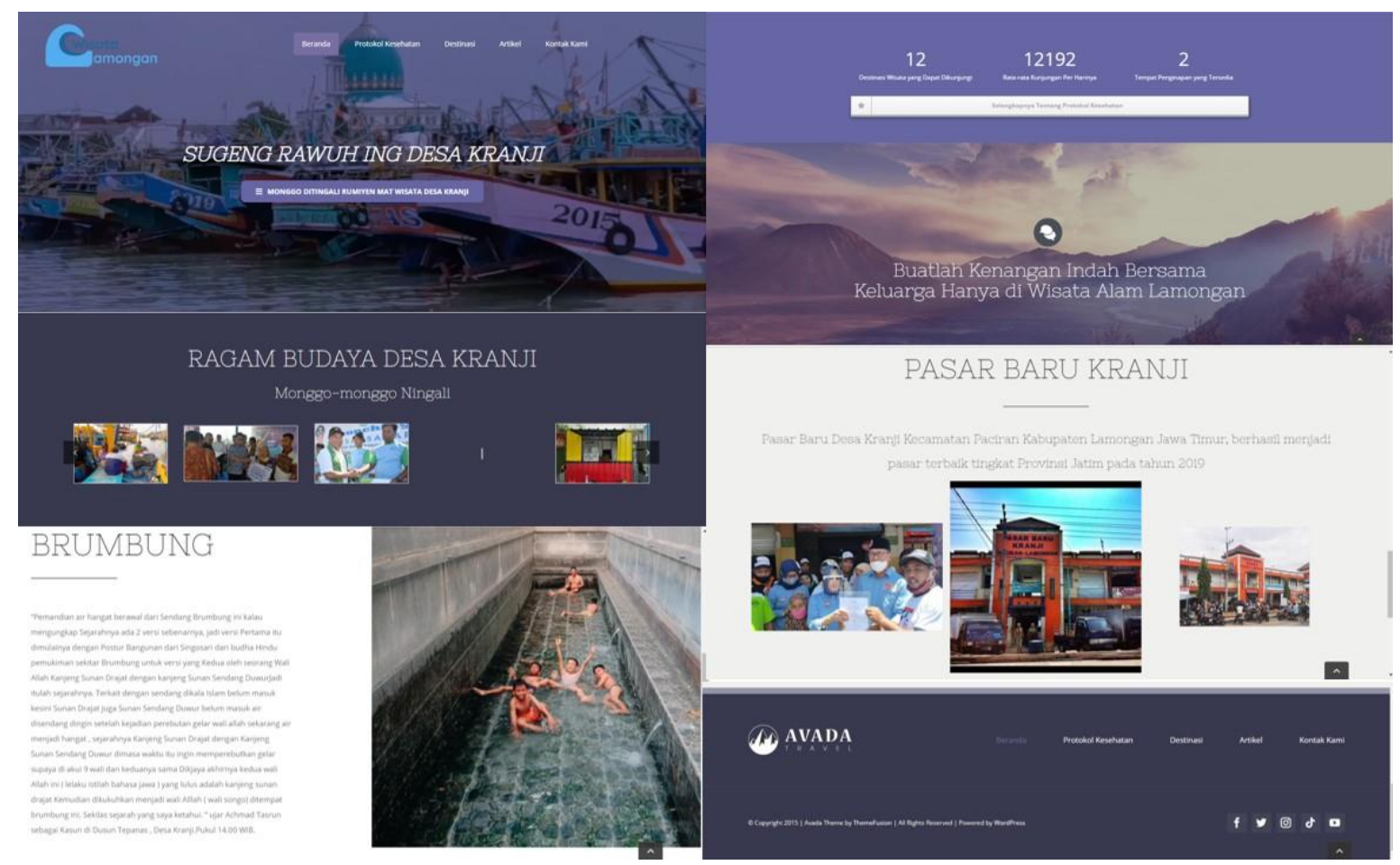

Gambar 3. Tampilan halaman website yang dibuat oleh peserta pelatihan

Secara umum website yang merupakan salah satu luaran program pengabdian kepada masyarakat ini sudah tersusun dengan baik dan dapat memberikan informasi kepada masyarakat terkait potensipotensi desa Kranji. Meski demikian, perlu dilakukan perbaikan di beberapa bagian untuk menyempurnakan tampilan maupun konten dari website tersebut. Pengelolaan serta pembaharuan informasi juga perlu dilakukan secara kontinu untuk menjamin keberlangsungan website serta memastikan info-info terbaru dapat tersampaikan kepada masyarakat luas. Website yang dibuat oleh peserta selanjutnya menjadi hak milik dari pemerintah desa Kranji untuk dapat dimanfaatkan sesuai dengan kebutuhan dan program pemerintah desa.

Berdasarkan hasil kuisioner yang diberikan di akhir pelatihan, dapat disimpulkan bahwa kegiatan pelatihan ini mendapat respon positif dari peserta. Terbukti dari penilaian umpan balik terkait materi, narasumber, dan fasilitas yang diberikan. Hasil kuisiner menunjukkan rata-rata nilai untuk ketiga aspek tersebut sebesar 4,3 dari skala 5. Gambar 4 menunjukkan penilaian peserta pada aspek materi yang meliputi 1) kesesuaian materi terhadap kebutuhan peserta, 2) kemudahan materi untuk diterima dan diterapkan, serta 3) keurutan dan kejelasan sistematika materi yang disampaikan. Penilaian dilakukan oleh sepuluh orang peserta dan didapatkan nilai rata-rata sebesar 4,4 untuk aspek pertama, sebesar 4,3 untuk aspek kedua dan 4,2 untuk aspek ketiga. Dengan demikian, rata-rata nilai keseluruhan dari segi materi adalah 4,3 dari skala 5 . 


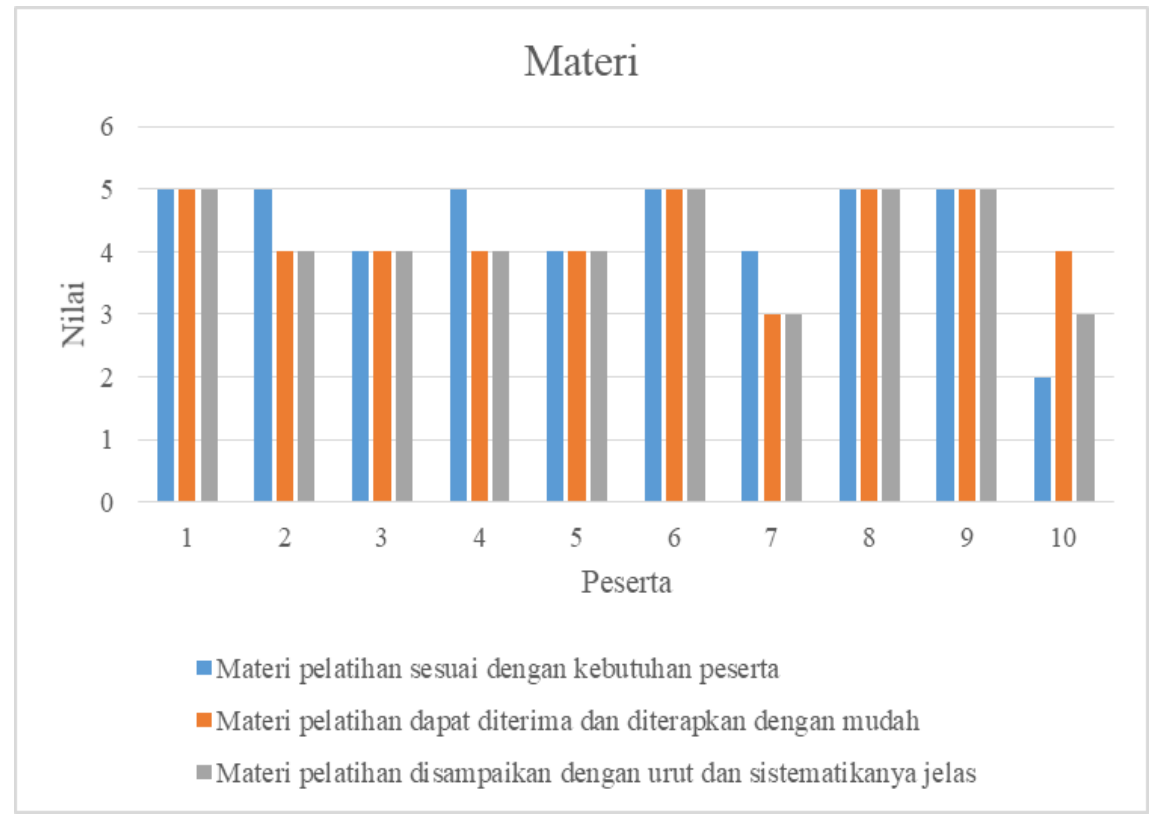

Gambar 4. Penilaian peserta terkait materi

Gambar 5 menunjukkan penilaian peserta terhadap narasumber pelatihan yang meliputi penguasaan materi, pemberian kesempatan tanya jawab, dan penyajian materi yang jelas dan beruruan. Dari sepuluh penilaian peserta didapatkan rata-rata nilai untuk tiap aspek berturut-turut 4,4 untuk aspek pertama dan kedua serta 4,1 untuk aspek ketiga. Dengan demikian didapat rata-rata total untuk nilai narasumber adalah 4,3. Penilaian fasilitas ditunjukkan pada Gambar 6 yang dilihat dari segi ruangan dan konsumsi. Nilai rata-rata masing-masing aspek adalah 4,1 dan 4,5. Sehingga didapat rata-rata total sebesar 4,3.

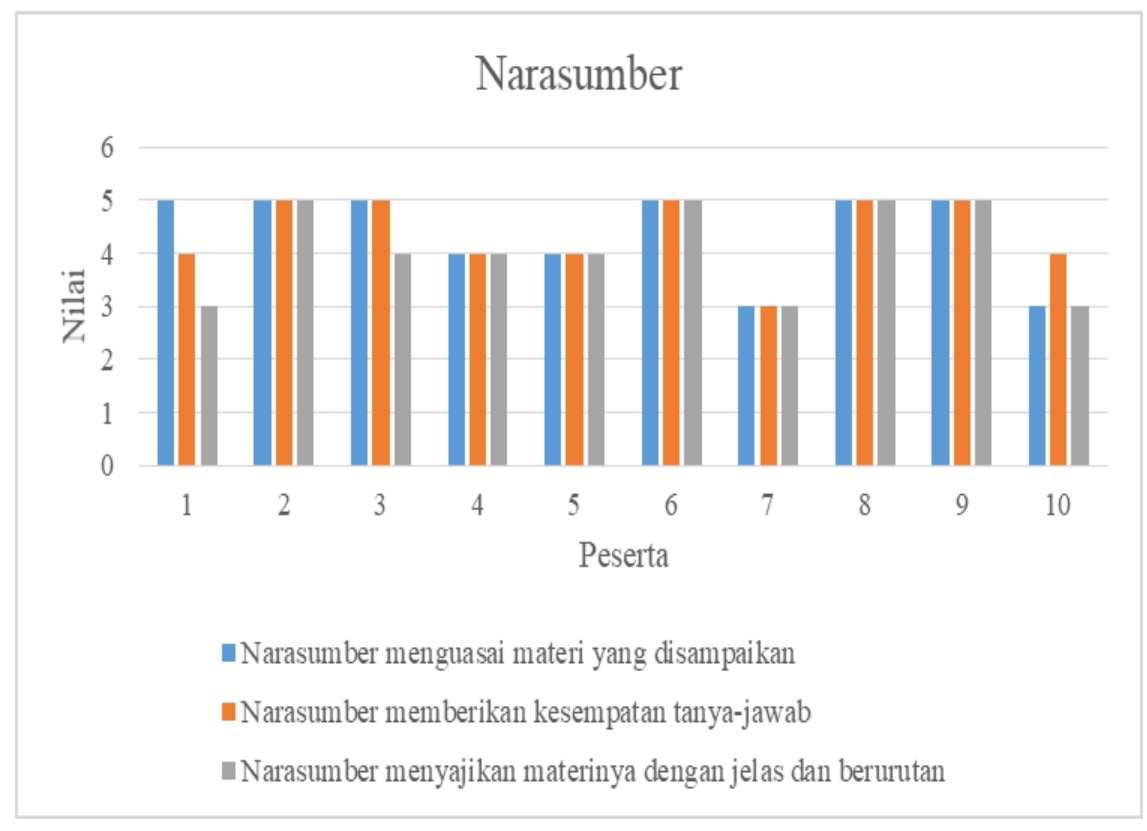

Gambar 5. Penilaian peserta terkait narasumber 


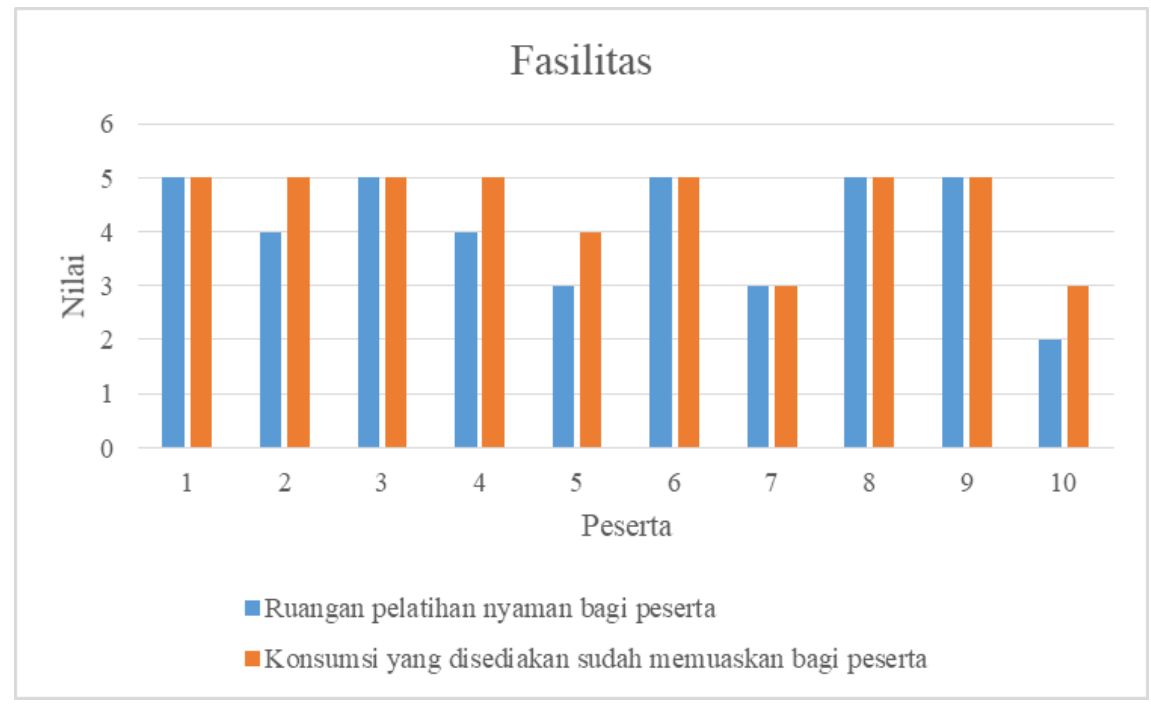

Gambar 6. Penilaian peserta terkait fasilitas

Dibalik keberhasilan program ini, tim pengabdian kepada masyarakat menemui beberapa kendala dalam proses pelaksanaan kegiatan. Salah satunya adalah sulitnya menjalin komunikasi secara daring dengan peserta. Kecenderungan peserta lebih pasif dalam komunikasi melalui grup Whatsapp yang dibuat untuk koordinasi. Sehingga, hal ini menghambat proses pendampingan dan monitoring. Kendala ini menjadi salah satu evaluasi tim pengabdian kepada masyarakat yang akan dijadikan sebagai bahan pertimbangan pada pelaksanaan kegiatan pengabdian kepada masyarakat selanjutnya.

Melihat potensi daerah Lamongan dan antusisme warga dalam mengikuti kegiatan pelatihan, sangat mungkin dilakukan pembinaan lebih lanjut guna memaksimalkan potensi yang ada. Kegiatan pelatihan ini merupakan langkah awal dari rencana pengabdian kepada masyarakat berkelanjutan yang akan diterapkan pada masyarakat di Kota Lamongan. Secara keseluruhan kegiatan pengmas direncanakan secara multitahun selama 3 tahun berturut-turut. Adapun topik yang telah disepakati dengan sasaran pengmas adalah: (i) Tahun 2021: Fasilitasi informasi terhadap produk-produk unggulan daerah, Desimilasi sains dan teknlogi bagi masyarakat serta promosi pariwisata; (ii) Tahun 2022: pengelolaan media promosi produk dan potensi alam unggulan berbasis teknologi informasi; dan (iii) Tahun 2023: pengembangan sayap usaha tingkat global melalui media teknologi informasi disertai penjalinan mitra luar daerah baik skala nasional atupun internasional.

\section{KESIMPULAN}

Berdasarkan hasil dan pembahasan di atas, dapat disimpulkan bahwa kegiatan pengabdian kepada masyarakat dilakukan dalam empat tahapan, yaitu : koordinasi, pelatihan, penugasan, dan evaluasi. Hasil atau output dari kegiatan pengabdian kepada masyarakat berupa website yang dapat diakses pada tautan https://wisatalamongan.com. Berdasarkan hasil pretest dan posttest didapatkan peningkatan nilai peserta sebesar $25 \%$. Hal ini senada dengan hasil umpan balik yang menunjukkan respon positif peserta terhadap materi, narasumber, dan fasilitas saat pelatihan dengan nilai 4,3 dari 
skala 5. Salah satu kendala pelaksanaan kegiatan pengabdian kepada masyarakat adalah sulitnya komunikasi secara daring dengan peserta. Hal ini menjadi evaluasi tim pelaksana sebagai bahan pertimbangan untuk kegiatan pengabdian kepada masyarakat selanjutnya. Pelatihan yang telah dilakukan menjadi awal program pengabdian kepada masyarakat berkelanjutan di kota Lamongan

\section{UCAPAN TERIMAKASIH}

Penulis mengucapkan terima kasih kepada Fakultas Sains dan Teknologi Universitas Airlangga yang telah memberi dukungan financial terhadap pengabdian ini melalui RKAT Fakultas Sains dan Teknologi tahun anggaran 2021.

\section{DAFTAR PUSTAKA}

E.Prasetyo. (2019). Teknologi Informasi dan Komunikasi dalam Pariwisata Indonesia. Kompasiana. https://www.kompasiana.com/epras/5d418b4d097f366a40324a62/pemanfaatan-teknologiinformasi-dan-komunikasi-dlam-pariwisata-indonesia

Komalasari, R. (2020). Manfaat teknologi informasi dan komunikasi di masa pandemi covid 19. TEMATIK-Jurnal Teknologi Informasi Dan Komunikasi, 7(1), 38-49.

Nadhiroh, N. (2018). Pengaruh pendapatan perkapita, produk domestik regional bruto, inflasi, dan belanja modal terhadap penerimaan pajak daerah (studi kasus kabupaten dan kota di Provinsi Jawa Tengah tahun 2016). Universitas Muhammadiyah Semarang.

Putra, R. R., Siti Khadijah, U. L., \& Rakhman, C. U. (2020). Pemanfaatan teknologi informasi dan komunikasi dalam penerapan konsep smart tourism di kabupaten Pangandaran. Jurnal Master Pariwisata (JUMPA), 7, 257-279. https://doi.org/10.24843/jumpa.2020.v07.i01.p12

Ritchi, H., Zulkarnaen, R. M., Dewantara, Z., Akuntansi, D., Ekonomi, F., \& Padjadjaran, U. (2018). Pemanfaatan teknologi informasi dalam upaya peningkatan aksesibilitas UKM (desa wisata) kepada pasar di lokasi wisata Pangandaran dan sekitarnya. Jurnal Pengabdian Kepada Masyarakat, 2(1), 36-40.

Rizkinaswara, L. (2019). Pentingnya Teknologi dalam Sektor Pariwisata - Ditjen Aptika. https://aptika.kominfo.go.id/2019/04/pentingnya-teknologi-dalam-sektor-pariwisata/

Romhadhoni, P., Faizah, D. Z., \& Afifah, N. (2018). Pengaruh Produk Domestik Regional Bruto (PDRB) Daerah terhadap Pertumbuhan Ekonomi dan Tingkat Pengangguran Terbuka di Provinsi DKI Jakarta. Jurnal Matematika Integratif, 14(2), 113-121. https://doi.org/10.24198/jmi.v14i2.19262

Rosyid, F. A., Ginting, F. A., \& Wibowo, A. P. (2020). Analisis Dampak Investasi Terhadap Perekonomian Daerah: Studi Kasus Investasi Pertambangan Mineral Logam Provinsi Papua. Indonesian Mining Professionals Journal, 2(1), 11-28. https://doi.org/10.36986/impj.v2i1.18

Syahputra, R. (2017). Analisis faktor-faktor yang mempengaruhi tingkat pertumbuhan ekonomi di Indonesia. Junal Samudra Ekonomi, 1(2), 183-191.

Wardana, B. S., Budhi, M. K. S., \& Yasa, L. G. W. M. (2014). Faktor-faktor yang mempengaruhi pertumbuhan ekonomi dan dampaknya terhadap kesempatan kerja di provinsi Bali. E-Jurnal Ekonomi Dan Bisnis Universitas Udayana, 131-139. 